\title{
AN ANALYSIS OF STUDENTS' WRITING SKILL ON ENGLISH DESCRIPTIVE TEXT
}

\author{
Dewi Purnamasari ${ }^{1}$, Didin Nuruddin Hidayat ${ }^{2 *}$, Lia Kurniawati ${ }^{3}$ \\ ${ }^{1,2,3}$ UIN Syarif Hidayatullah Jakarta \\ *didin.nuruddin@uinjkt.ac.id
}

\begin{abstract}
This study analyzed the writing skills in English descriptive text. There are five indicators in writing descriptive text: content, organisation, grammar, vocabulary, and mechanics. Therefore, this study aimed to investigate the students' writing skill on descriptive text related to the five indicators of English descriptive text and investigated the difficulties in writing English descriptive text. This research study used a descriptive quantitative research design. The participants were eighth-grade students at SMPN 16 South Tangerang. The data gained from students' writing descriptive text test and analyzed by using Heaton's theory. The result showed that: 1) $43 \%$ of students obtained scores ranging from average to good in writing content, 2) 44\% of students obtained scores ranging from average to good in writing organization, 3) 37\% of students obtained scores ranging from average to good in using grammar, 4) $33 \%$ of students obtained scores ranging from very good to excellent in using vocabulary, 5) $27 \%$ of students obtained scores ranging from very good to excellent in writing mechanics. Further, the study found some difficulties the students face when writing descriptive. First, students cannot develop their ideas. Second, the students have insufficient knowledge about the subject that will be described. Third, the students have difficulties in using a simple present tense.
\end{abstract}

Keywords: descriptive text; English learning; writing skill

\section{A. INTRODUCTION}

Writing is a crucial skill in learning the English language. Writing is an English language skill that the students must learn because writing activity can improve their thinking skills and help them to develop other language skills. In line with that, writing has an essential role in fostering language acquisition. As a productive language skill, writing involves some aspects of language such as words, sentences, and large chunks of writing to communicate. Asiah, Ardian, and Amri (2020) argue that improving writing skills is crucially needed because the students can express their feeling, knowledge, and ideas in a piece of writing. In line with that, Ningsih (2016) claims that writing is one activity that transfers the knowledge in the 
human brain into written form. The explanation above shows that writing is an essential skill that students should master in learning English foreign language.

Writing is an expressive activity meaning that the learners can express their ideas and knowledge by putting them into written form. Perhaps, the learners can express their ideas effectively, convey their thoughts into good sentences, and put them in a writing form. Furthermore, the learners can improve their thinking skills and thoughts through writing (A. D. Jayanti, 2019). Therefore, the learners need to stimulate their writing skills by getting sufficient writing practice. By practicing, perhaps can stimulate the learners to write the text effectively and correctly. Rahmah (2017) argues that writing aims to inform readers about the authors' ideas. Pratiwi (2015) supports (Pratiwi, 2015)this statement, stating that the main target of writing is to present the information to the readers. Writing is one of the activities used by the writer to communicate with the reader. When the students have ideas or knowledge in their minds, they can use writing to express their ideas. Perhaps, the writer able to communicate and express their ideas with readers. Therefore, the learners need to consider the readers' understanding of the text and get the main point or ideas clearly from their text. Moreover, writing can be a complex activity because the students convey the ideas into written form and notice several aspects of writing, such as good grammar, spelling, clear point, etc.

Descriptive text describes or says something to the reader (Fitriani et al., 2019; Jayanti et al., 2019). This type of text provides details about something, such as people, animals, things, and places. Suminar and Putri (2018) reveal that text descriptive is the text describing the person, animals, thing, and place with a clear explanation to give readers a piece of information and understanding about the object described. Therefore, the reader can get the information about the new object written by the writer in descriptive text, and the writers will describe the object clearly and get a clear picture of the object. The object's explanation is essentially to make the reader understand and get the knowledge from the text.

Furthermore, the learners should involve two generic structures in write text descriptive: identification and description. The learners should complete the text with these two generic structures. Besides, the learners should pay attention to the language use in descriptive text. The structure or language use have an important role in writing descriptive text. Sometimes the students face difficulties to make descriptive text correctly. Some of them write text descriptive without following the terms of good writing in descriptive text. Therefore, 
it is important to review the students' descriptive text writing to improve their writing skill, especially in writing descriptive text.

Some research studies have been conducted to discuss the descriptive text related to the cases above. The first research from Ratnaningsih and Azizah (2019) focused on the technical error of writing a descriptive text. The purpose of their study was to investigate the errors and mistakes in writing a descriptive text. As a result, the researcher found that students' typical mistakes in writing descriptive text were capitalization and sentence errors. Another research analyzed the using prefixes and suffixes in writing a descriptive text (Mena \& Saputri 2018). Their research aims are to describe the use of prefixes and suffixes in descriptive text. On the other hand, they also explore the difficulties in writing text descriptive. As a result, the students used found thirty-two prefixes and suffixes in writing text descriptive. They found some problems students face in writing descriptive text, such as the learners having a limited vocabulary and grammatical skills. Therefore, those problems influence on their writing skill in writing descriptive text.

Based on the previous research above, it is important to get an in-depth review of the students' writing text descriptive. Therefore, the researcher wants to know the students' writing skills in write text descriptive. Furthermore, this research study aims to analyze the students' English writing descriptive text using Heaton's theory. The focus study is to analyze the English descriptive text test of students based on the five indicators. The second is the difficulties in write a text descriptive based on Heaton's theory.

\section{Writing}

Writing is an activity that can improve students' vocabulary, grammatical structure, and idiom. Hossain (2015) mentions some purposes of writing. Writing can be a medium for the writer to communicate with a reader, explore the subject. The writer can express their idea and feeling without pressure face to face communication. Meanwhile, Pratiwi (2015) states that writing is a complex activity. It involves some skills, such as getting an idea to write, organizing ideas, deciding the topic to write, and determining to convey the words into a written form.

Ahlsén and Lundh (2007) mention some purposes of writing. First, writing to entertain means that writing may involve the readers' feelings through the emotion or plot. The second is writing to information refers to tell the ideas or feeling about something. The last is writing 
to persuade means that writing can stimulate and invite readers to determine whether they agree or support what is stated by the author. Furthermore, Hourani (2008) classified the main criteria for good writing. They are a good grammar, clear point, length, time logical, spelling, and grammatical correct. Therefore, the writer needs to notice the criteria mentioned above to make the writing text correctly. When the readers read the writing text, they will understand and get the text's main point. Harmer (2004) claims some writing stages: planning, drafting, editing, and final draft. Therefore, before writing, the writer needs to make a text concept and follow the writing stages. Then, she/he will not be overlap with the topic of writing.

\section{Descriptive Text}

Descriptive text consists of descriptions of animals, persons, things, places, etc. (Ushchapovska, 2020). This statement is supported by Urunami et al. (2017), who states that descriptive text consists of information about a particular thing, Such as a description of an object through writing. Basically, it provides information about the subject, the fact, and their behavior. Descriptive is the text describing an object person, animals, thing, and place with clear and detailed explanation. In this case, the readers can visualize an object described. Therefore, the writers will create their feeling and get a clear view of the object described, and the reader can imagine, feel, and have an overview of the subject being read. Furthermore, description activity describes an object to make the readers understand about the object described.

Rusmawan (2017) states that English descriptive text consists of two generic structures: identification and description. Identification consists of introducing the general description of the topic and the special characteristics of the object, places, or person described. The description consists of the illustration of physical features, explanation of the purpose, explanation of people, explanation of features and their use, explanation of interesting facts description properties. In identification, the students can identify the subject. In this part, the learner introduces the subject. In a description, the students can describe a particular part, characteristics, and qualities of the object. Besides that, the students should involve the language features in writing descriptive text. Such as a grammatical function, vocabulary, and mechanics. Brown (2001) divided some English descriptive text indicators: content, organisation, grammar, vocabulary, and mechanics. 


\section{Content}

Descriptive text is text in English that clearly described the properties attached to something. It can be humans, animals, plants, or inanimate objects. Content refers to the topic that uses by the writer in writing descriptive text. In this case, the writer should find a suitable topic in writing the text. Also, the detail of the topic also important in writing descriptive text. The writer should write a descriptive text with complete detail and suitable for the topic. According to Brown (2001), content in writing English text descriptive was 30\%. Therefore, the writer needs to pay attention to the content in write text descriptive.

\section{Organisation}

Organisation refers to the good arrangement in descriptive text. This part consists of the generic structure of the descriptive text, namely identification and description. Identification is essential in write text descriptive. It uses to avoid the general statement in the paragraph. It means that the learner should identify a particular thing. In this case, the learner can identify a subject that will be described in the text. In identification, the learner introduces or identifies the subject. It is part of the paragraph that consists of the introduction of the subject. The second is a description, and this part consists of a detailed explanation of the subject described. In this part, the subject describes specifically, such as the characteristics, qualities, and parts. Novita (2014) states that a description is a part of a paragraph explaining the object described. Therefore, the learner should describe the information completely that is related to the topic. Then, writing should organize ideas well.

\section{Grammar}

The grammatical features in the descriptive text are focused on using language characteristics. Furthermore, the sentence used in the descriptive text are simple present tense, adjective, agreement, and an action verb. Based on Toago and Usman (2013) statements, which state that in writing descriptive text, the learner uses simple present tense because it tells the readers about the descriptions and uses the adjective to clarify the noun. For instance, sweet cat, handsome man, beautiful places, etc. In contrast, the action verb is used to show the action. The writer should be mastered in simple present tense and some language features in the descriptive text such as walk, read, sit, etc. Due to the good writing of the descriptive text, it is also easier for them to express their ideas into good writing. In line with that, simple present 
tense has an important pattern to learn by the students, such as subject, verbal, and nominal sentences.

Furthermore, the adjective is used to write English descriptive text to give the reader more information about the subject. The adjective is modified from the pronoun or noun to make the reader interested and create excitement in their word. Butt et al. (2012) claim that adjectives in descriptive text describe the subject using the words because they give information about the object described in clauses, nouns, or noun phrases.

\section{Vocabulary}

Vocabulary is an essential part of writing descriptive text. In this case, the writer can make the reader understand and get the text's main point from the vocabulary used in write text descriptive. The learner can tell the reader about their ideas and feeling by conveying their ideas into the sentences and comprehend the reader. In this part, Johnson et al. (2013) mentions the criteria of vocabulary used in writing English descriptive text. He states that the vocabulary used should have an effective choice to represent the subject and correctly use the word and words. It means that the learner should pay attention to choosing the correct word that suitable for the context. The use of the wrong in writing text descriptive will make a meaning error and difficult to understand.

\section{Mechanics}

Heaton (1988) argues that mechanics refers to the writer's ability to write the text correctly using punctuation and spelling. Based on Afifuddin (2016), mechanics in writing means using capitalization, punctuation, and spelling correctly. Punctuation is a term that refers to marks that are used to organise and clarify texts, primarily by separating or connecting words, clauses, and phrases. According to Oshima and Hogue (2006), proper punctuation is critical because it conveys meaning. The spelling indicates how the word appears. If the writer used incorrect spelling, the result will be unintelligible words.

\section{Heaton's Theory}

Writing test is an important part of learning writing. Knowing the student's writing achievement can also show the students' skill to write a text descriptive. In this part, to know the students' achievement in writing skill, the teacher ordered the students to write text descriptive and give scoring on their writing test. There are some criteria in scoring English 
writing test; one of them is using criteria of scoring by Heatons's theory. Heaton (1988) divides some components in a scoring writing test. He classified them into content, which consists of the idea of writing. This organization concerns the writers' ideas, grammar, or language uses that concern choosing the correct word, and the last mechanics, which refers to punctuation, spelling, and capitalization. While for the criteria of scoring, Heaton classified into four categorizations as follows.

Table 1 Categorization of five indicators in students writing skill

\begin{tabular}{|c|c|}
\hline Score & Categorization of scoring \\
\hline $3.51-4$ & Excellent - very good \\
\hline $2.51-3.50$ & Good - average \\
\hline $1.51-2.50$ & Fair - poor \\
\hline $1-1.50$ & Very poor \\
\hline
\end{tabular}

\section{B. RESEARCH METHOD}

This research study used a descriptive quantitative research design. The purpose of this research study was to investigate the students' writing skills in descriptive text. This research study focused on analyzing the five English descriptive text test indicators by using Heaton's theory. The participants of this research study were the eighth-grade students of SMPN 16 South Tangerang. 180 students consisted of 75 male students and 105 female students.

The research instrument of this research was the English descriptive text test of the students. The researcher developed the instrument test from Brown and Abeywickrama (2010), consisting of five indicators: content, which consisted of topic and detail, an organization consisting of identification and description, grammar, which uses present tense and agreement, vocabulary, and mechanics. In this case, the students were asked to write an English descriptive text. Furthermore, the students' writing English descriptive text test was analyzed using Heaton's theory and writing testing scoring.

\section{FINDING AND DISCUSSION}

\section{Findings}

The finding of this study presents the analysis of English descriptive text using Heaton's theory assessment. Furthermore, each category of students' writing skills of five English Descriptive text indicators is presented in each category. 


\section{Analysis of Five Indicators of English Descriptive Text}

The data from students' descriptive text test was analyzed using Heaton's Theory. After that, the researchers analyzed English descriptive text into indicators, namely content, organization, grammar, vocabulary, and mechanics. Then, the researchers analyzed the problems for each indicator in writing English descriptive text.

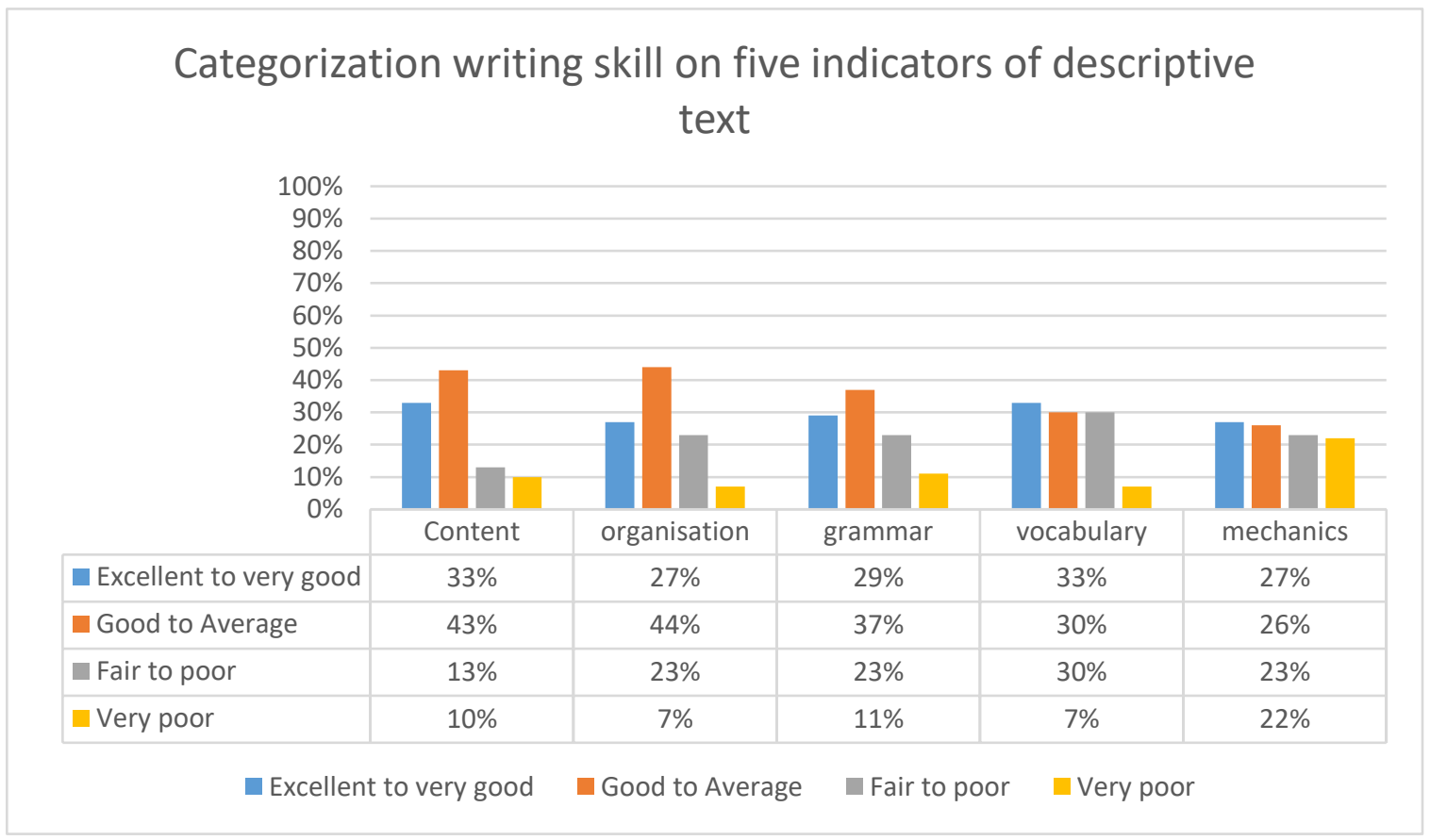

Figure 1. The categorization of English descriptive text

\section{Students' Writing Skill in Write the Content of the Descriptive text}

Content is the first indicator in English descriptive text. This part consists of the topic and the details in write text descriptive. Figure 1 above showed that $30 \%$ of students from 180 students were very good to excellent. 60 students have a high score in writing content of descriptive text. $43 \%$ of students were average to good. Meanwhile, $13 \%$ of students got fair to poor, and $10 \%$ were very poor in writing a descriptive text.

\section{Students' Writing Skill in Write the Organization of the Descriptive Text}

Next organization is the second indicator in English descriptive text. The organization consists of the identification and the description of English descriptive text. The students' writing skill in the organization was described on Figure 1 above. The data showed that 27\% of students were very good to excellent in writing organization, and $44 \%$ of students were average to good. Meanwhile, in writing an organization, $23 \%$ of the students were fair to poor, 
and $7 \%$ of students were very poor. The high score of 3.51 to 4 for the organization showed a complete and clear explanation in describing and identifying the object in English descriptive text. The result showed that $27 \%$ of students wrote a complete and clear explanation in English writing descriptive text. Simultaneously, $44 \%$ of students were good to average scores in writing identification and description.

\section{Students' Writing Skill in Write the Grammar of the Descriptive text}

Grammar is the third indicator in English descriptive text. This part focuses on arranged the sentence with the correct grammar. The grammar used in the descriptive text is simple present tense, adjective, action verb, and agreement. Furthermore, the students' writing skill in writing grammar was described on the figure above. It showed that $29 \%$ of the students were average to good, and $37 \%$ of the students were good to average in writing grammar. Meanwhile, $23 \%$ of the students were fair to poor, and $11 \%$ were very poor, writing descriptive text grammar.

\section{Students' Writing Skill in Write the Vocabulary of Descriptive text}

Next, the fourth indicator is using vocabulary in write text descriptive. The student's vocabulary in writing skills was described based on Figure 1 above. It showed that $33 \%$ of students were very good to excellent and $30 \%$ of students were average to good. Meanwhile, $30 \%$ of students were poor to fair, and $7 \%$ of students were very poor writing vocabulary in English descriptive text.

\section{Students' Writing Skill in Write the Mechanics of Descriptive Text}

Next, Mechanics is the five indicators in English descriptive text. The mechanics concern the use of punctuation, spelling, and capitalization. The student's writing skill was described in Figure 1 above, and it showed that $27 \%$ of students were very good to excellent, and $26 \%$ of students were good to average in writing mechanics of descriptive text. Meanwhile, $23 \%$ of students were poor to pair, and $22 \%$ of students were very poor.

\section{Discussion}

The calculation data above shows that $33 \%$ of the students have excellent writing content in English descriptive text. 60 students from 180 students who write the text correctly between the topic and the detail are suitable. $43 \%$ of students were categorized as average to 
good, which means that 79 students write the content in writing with the suitable topic, but the detail is not clear. Meanwhile, $13 \%$ of students have a poor to fair, which shows that 23 students have poor knowledge in writing descriptive text content. The last $10 \%$ of students were very poor $10 \%$ in writing the descriptive text's content. 18 students cannot write content in descriptive text clearly. Students still face difficulties determining the suitable topic and the details in writing English descriptive text. According to Rusmawan (2017), content in writing descriptive text consists of the topic and detail of the text. In this case, the students should write the text suitable between the topic and the detail to make the text understandable, and the readers get the main point of the text.

The second indicator is the organisation, which consists of a generic structure of the descriptive text, namely identification and description. The data shows that $27 \%$ of the students are very good to excellent in writing organisation of the text. It means that 49 students write the generic structure, and the generic structure is complete and clear. Besides, $44 \%$ of the students are very good to excellent. It shows that 79 students write the generic structure completely, but the explanation is not clear. Meanwhile, $23 \%$ of students get poor, and $7 \%$ of students get very poor. It means that 41 students are face difficulties in writing the generic structure of the descriptive text. Therefore, it showed that some students have a problem to identify and describe the object. They cannot develop their idea and information through the object. Indriyani (2013) states that the students' difficulties in write text descriptive are in the generic structure and organising the idea. She found that the students make mistakes in writing descriptions $90 \%$ while identifying the object. In this case, the students have difficulties describing the problem because they lack the knowledge and cannot clearly describe the object. In line with that, Yoandita (2019) also found that the students' writing problems organize ideas and develop their ideas.

The third indicator is the use of grammar in writing descriptive text. The third part concerns language features used in writing descriptive text; simple present tense uses descriptive text and some language features, such as action verb, adjective, agreement etc. The data shows that $29 \%$ of the students have very good to excellent writing skills, and $37 \%$ of students have good to average to use grammar in writing descriptive text. It means that 51 students have good grammar, and 65 students have a few grammar mistakes in write text descriptive. Meanwhile, $23 \%$ have poor, and $11 \%$ have very poor in writing grammar. It means 
that almost 60 students have difficulties in writing the grammar of the descriptive text. The students face difficulties using language features that might be caused by their not knowing the basic structure of simple present tense. They are still confused in using singular and plural in the simple present tense. It supported Indriyani (2013), who found that the students' tense mistakes in writing descriptive text were $9.8 \%$. Besides that, they are still confused about the use of verbs and adjectives in a sentence. They make a mistake in writing a sentence of verbal and nominal.

The fourth indicator is vocabulary. Based on the data, $33 \%$ of students have good to excellent in using vocabulary in writing descriptive, and $30 \%$ have good to average. It shows that 60 students have a very good vocabulary in writing English descriptive text, and 54 students have a good vocabulary. It means that more than half of eighth-grade students do not have a problem with their vocabulary. Moreover, $30 \%$ of students have poor, and $7 \%$ of students have very poor vocabulary. It showed that 66 students have difficulties with their vocabulary to write text descriptive. The use of vocabulary in English descriptive text is crucially needed because it makes the text comprehensible (Brown \& Abeywickrama, 2010). The use of the wrong vocabulary made the reader misunderstanding and did not get the text point. In this case, the students use vocabulary that was not related to the topic, and some used Indonesian words to write a descriptive text. It makes the reader do not get the main point and information from the text. Therefore, students need to improve their vocabulary knowledge.

The last indicator is mechanics in write text descriptive. The data shows that $27 \%$ of students have very good to excellent, and $26 \%$ of students have average to good in using mechanics while writing descriptive text. It means that 97 students have no problem with spelling, punctuation, and capitalization in writing skills. Moreover, $23 \%$ of students have poor, and $22 \%$ have very poor in using mechanics. 83 of the students have mistakes and errors in spelling, punctuation, and capitalization in writing descriptive text. Their mistakes caused they have lack of knowledge about the mechanism in writing skill. The students put a comma at the end of the sentence, and the students were still confused between the dependent and independent clauses. Hence, it makes ambiguity what the text means. On the other hand, the students write mispelling words in writing descriptive text. Graham et al. (2002) state that all the words have meaning, and the use of miss-spelling of the word makes it has a different 
meaning or makes the word have no meaning. Therefore, to make the reader understand the text, it is important to write the mechanics correctly.

\section{CONCLUSION AND SUGGESTIONS}

\section{Conclusion}

Based on the discussion above, it can be concluded that the students' writing skill of English descriptive text was average to good. It was found that $30 \%$ of students were very good to excellent and $43 \%$ were average to good writing content. Meanwhile, $13 \%$ of students were poor to fair, and $10 \%$ of students were very poor in writing descriptive text content. Furthermore, in writing description and identification, $27 \%$ of students were very good to excellent, $44 \%$ were average to good, $23 \%$ were poor to fair, and $7 \%$ of students were very poor. Next, in using grammar, $29 \%$ of students were very good to excellent, $37 \%$ were average to good, $23 \%$ were poor to fair, and $11 \%$ were very poor. In writing vocabulary, $33 \%$ of students were very good to excellent, $30 \%$ were average to good, $30 \%$ were poor to fair, and $7 \%$ were very poor. The last is writing mechanics. $27 \%$ of students were very good to excellent, $26 \%$ were average to good, $23 \%$ were poor to fair, and $22 \%$ were very poor.

According to the discussion above, the difficulties encountered when writing descriptive text are as follows: first, when writing the descriptive text's content, students encountered difficulties determining the appropriate content and providing an insufficient explanation of detail. Second, the students are unable to develop their ideas and have a limited understanding of the subject being discussed. As a result, they are unable to adequately describe the object. Thirdly, they struggle with the simple present tense. Fourth, students struggle with selecting appropriate vocabulary when writing descriptive text. Finally, they made an error in their mechanics because they misspelt words and were unsure of proper punctuation.

\section{Suggestion}

Regarding this study's result and conclusion, the researcher would like to suggest the English teacher give a deeper and clear explanation about the descriptive text, especially in generic structure. In this case, the teacher can give brainstorm about the descriptive text before giving them the task. Therefore, the students can build their idea related to the topic in writing descriptive text. Next, the teacher is suggested to stimulate and give motivation to students to 
improve their vocabulary knowledge. For the next researcher, the last is important to research different aspects of English descriptive text that were not discussed in this study.

\section{REFERENCE}

Afifuddin. (2016). An analysis of students' errors in writing decriptive text. EEJ: English Education Journal, 7(1), 130-139.

Ahlsén, E., \& Lundh, N. (2007). Teaching writing in theory and practice; A study of ways of working with writing in the 9th grade. Stockholm Institute of Education.

Asiah, N., Ardian, E., \& Amri, S. (2020). A study on the student's factor difficulty in writing narrative text ar VII grade of MTS Sabilal Muthadin Tembilahan. J-Shelves of Indragiri (JSI), 1(2), 84-97.

Brown, D., \& Abeywickrama, P. (2010). Language assessment principles and classroom practices (2nd ed.). Pearson Education.

Brown, H. D. (2001). Strategies for success; A practical guide to learning English. Longman Pearson Education.

Butt, D., Fahey, R., Feez, S., \& Spinks, S. (2012). Using Functional Grammar: An explorer's guide. Palgrave Macmillan.

Fitriani, F., Nur, R. H., Bustamin, B., Ali, S. M., \& Nurisman, N. (2019). Improving Students' Descriptive Text Writing by Using Writing in the Here and Now Strategy at the Tenth Grade Students of Vocational High School. International Journal for Educational and Vocational Studies, 1(6), 632-636. https://doi.org/10.29103/ijevs.v1i6.1802

Graham, S., Harris, K. R., \& Chorzempa, B. F. (2002). Contribution of spelling instruction to the spelling, writing, and reading of poor spellers. Journal of Educational Psychology, 94(4), 669-686. https://doi.org/10.1037/0022-0663.94.4.669

Heaton, J. B. (1988). Writing English Language Test. Longman.

Hossain, M. I. (2015). Teaching Productive Skills to the Students: A Secondary Level Scenario. BRACC University.

Hourani, T. M. Y. (2008). An analysis of the common grammatical errors in the English writing made by $3 r d$ secondary male students in the Eastern Coast of the UAE.

Indriyani, R. P. (2013). A genre analysis of the difficulties in writing descriptive text. Muhammadiyah University of Surakarta.

Jayanti, A. D. (2019). Students' Writing Ability on English Descriptive Text at Grade VIII. Academic Journal of English Language and Education, 3(1), 71-94.

Jayanti, D., Husna, N., \& Hidayat, D. N. (2019). The validity and reliability analysis of English National Final Examination for junior high school. VELES Voices of English Language Education Society Journal, 3(2), 128-135. https://doi.org/10.29408/veles.v3i2.1551 
Johnson, M. D., Acevedo, A., \& Mercado, L. (2013). What vocabulary should we teach? Lexical frequency profiles and lexical diversity in second language writing. Writing \& Pedagogy, 5(1). https://doi.org/10.1558/wap.v5i1.83

Mena, V. V., \& Saputri, K. (2018). Prefixes and Suffixes in the Descriptive Texts of Student ' S. English Community Journal, 2(1), 175-182.

Ningsih, S. (2016). Guided Writing to Improve the Students' Writing Ability of Junior High School Students. Efl Journal, 1(2), 129-140. https://doi.org/10.21462/eflj.v1i2.12

Novita, R. (2014). An Analysis of Grammatical Errors in the 1st Year Students' Writings at English Department, Andalas University. Vivid Journal, 3(2), 1-15.

Oshima, A., \& Hogue, A. (2006). Writing Academic English. Addison Wesley Publishing Company.

Pratiwi, K. D. (2015). Students' difficulties in writing English : A study at the third semester students of English education program At University of Bengkulu. E Journal Universitas Bengkulu, 1(2), 1-13.

Rahmah, L. S. (2017). Improving student's score in writing descriptive text through think talk write strategy. International Journal of English and Education, 6(4), 180-193.

Ratnaningsih, S., \& Azizah, A. (2019). Error Analysis in the Descriptive Text Writing of Vocational High School Students. Dinamika Ilmu, 19(1), 175-186. https://doi.org/10.21093/di.v19i1.1364

Rusmawan, P. N. (2017). Genre based Approach to Teach Writing Descriptive Text. JEES (Journal of English Educators Society), 2(2), 119-134. https://doi.org/10.21070/jees.v2i2.875

Suminar, R. P., \& Putri, G. (2018). The Effectiveness of TTW (Think-Talk-Write) Strategy in Teaching Writing Descriptive Text. Academic Journal Perspective : Education, Language, and Literature, 2(2), 300. https://doi.org/10.33603/perspective.v2i2.1666

Toago, A. P., \& Usman, S. (2013). the Ability of Students To Apply Simple Present Tense in Descriptive Text. ELTS: E-Journal of English Language Teaching Society, 1(2), 1-11.

Urunami, S., Bharati, D. A. L., \& Faridi, A. (2017). Group Grid and Roundtable for Teaching Writing of Descriptive Text. ELT Forum: Journal of English Language Teaching, 6(2), 176-183. https://doi.org/10.15294/elt.v6i2.20699

Ushchapovska, I. (2020). Multimodal Features of Descriptive Texts: Case Study of Coffee Brands. World Science, 3(1(53)), 23-26. https://doi.org/10.31435/rsglobal_ws/31012020/6907

Yoandita, P. E. (2019). An anlysis of student's ability and difficulties in writing descriptive text. JOEPALLT; Journal of English Pedagogy Linguistics Literature and Technology, $7(1)$. 